\title{
ADULT ATTRACTIVENESS AND OVIPOSITION PREFERENCE OF Bemisia tabaci (GENN.) (Homoptera: Aleyrodidae) B-BIOTYPE IN COTTON GENOTYPES
}

\author{
Arlindo Leal Boiça Júnior ${ }^{1 *}$; Zeneide Ribeiro Campos ${ }^{1}$; André Luiz Lourenção²; Alcebíades \\ Ribeiro Campos ${ }^{3}$ \\ ${ }^{1}$ UNESP/FCAV - Depto. de Fitossanidade, Via de Acesso Prof. Paulo Donato Castellane, s/n - 14884-900 - \\ Jaboticabal, SP - Brasil. \\ ${ }^{2}$ IAC, C.P. 28 - 13001-970 - Campinas, SP - Brasil. \\ ${ }^{3}$ UNESP/FEIS - Depto. de Fitossanidade, Engenharia Rural e Solos, Av. Brasil, 56 - Centro - 15385-000 - Ilha \\ Solteira, SP - Brasil. \\ *Corresponding author 〈aboicajr@fcav.unesp.br>
}

\begin{abstract}
The silverleaf whitefly Bemisia tabaci B-biotype is an important pest of cotton; it affects plant vigour, transmits geminivirus and reduces lint quality. In order to evaluate the resistance of cotton genotypes, Gossypium hirsutum (L.), to the whitefly Bemisia tabaci B-biotype, both free-choice and nochoice attractiveness and non-preference for oviposition tests were carried out in a shade house, at room temperature. Low attractiveness to adults of this whitefly was observed for plants of genotypes Fabrika, CNPA Ita 90, Makina, Coodetec 407, and IAC 01-639 CPA 02-24, which may represent a resistance component of these genetic materials to the insect. Genotypes BRS Aroeira, Coodetec 406, Fabrika, and Coodetec 401 presented the non-preference-for-oviposition type of resistance in the free-choice and nochoice tests. The numbers of trichomes and gossypol glands per $\mathrm{cm}^{2}$ were not suitable to evaluate nonpreference for oviposition of whitefly adults on cotton genotypes.

Keywords: Gossypium hirsutum L., Aleyrodidae, insecta, silverleaf whitefly, host plant resistance
\end{abstract}

\section{ATRATIVIDADE DE ADULTOS E PREFERÊNCIA PARA OVIPOSIÇÃO DE Bemisia tabaci (GENN.) (Homoptera: Aleyrodidae) BIÓTIPO B EM GENÓTIPOS DE ALGODOEIRO}

\begin{abstract}
RESUMO: Considerada importante praga do algodoeiro, a mosca-branca Bemisia tabaci biótipo B pode através de sua alimentação, diminuir o vigor das plantas, trasmitir vírus e prejudicar a qualidade da fibra. Visando avaliar a resistência de genótipos de algodoeiro, Gossypium hirsutum (L.), à mosca-branca Bemisia tabaci biótipo B, realizaram-se testes de atratividade e não-preferência para oviposição, com e sem chance de escolha, em telado, a temperatura ambiente. Verificou-se baixa atratividade das plantas dos genótipos Fabrika, CNPA Ita 90, Makina, Coodetec 407 e IAC 01-639 CPA 02-24 a adultos dessa mosca-branca, o que pode representar um componente de resistência destes materiais genéticos ao inseto. Os genótipos BRS Aroeira, Coodetec 406, Fabrika e Coodetec 401 apresentaram resistência do tipo não-preferência para oviposição, nos testes com e sem chance de escolha. Os números de tricomas e de glândulas de gossipol por $\mathrm{cm}^{2}$ não foram adequados para se avaliar a não-preferência para oviposição de adultos da mosca-branca em genótipos de algodoeiro.

Palavras-chave: Gossypium hirsutum L., Aleyrodidae, insecta, mosca-branca, resistência de plantas a insetos
\end{abstract}

\section{INTRODUCTION}

For the control of the whitefly Bemisia tabaci (Genn.) B-biotype, plant resistance should be used as an additional control tactic within the integrated pest management strategy in order to minimize the damages caused by this insect (Norman Jr. et al., 1996). Such resistance can be characterized by the occurrence of plant morphological and/or physiological traits that make them less or more preferred for feeding and ovi- position by the insects. Among the morphological traits, trichome density (McAuslane, 1996) and plant architecture can be underlined as important (Sippel et al., 1987). Also leaf pubescence in cotton has been reported as a very important morphological trait for oviposition preference. This trait was studied by Butler Jr. \& Henneberry (1984), who verified that the number of $B$. tabaci adults on glabrous-leaved cotton genotypes was smaller than in semi-glabrous or pubescent plants. 
With regard to the presence of chemical substances, the concentration of gossypol (Butter et al., 1990), sugars, tannin, o-dihydroxyphenol (Butter et al., 1990), as well as plant nutrition (Bentz et al., 1995) have been highlighted as the most important biochemical characteristics. Gossypol glands on the internodes favor B. tabaci populations, while their occurrence on the leaf area is considered detrimental (Butter \& Vir, 1989).

Considering the lack of data about effective control methods and the importance of B. tabaci B-biotype in cotton, we attempted to study the attractiveness and non-preference for oviposition of this whitefly for cotton genotypes as mechanisms involved in the resistance.

\section{MATERIAL AND METHODS}

The experiments were carried out in a shade house at room temperature. Attractiveness/repellency and non-preference for oviposition of the whitefly were evaluated for the following cotton genotypes PR 94227-918, IAC 01-639 CPA 02-24, CNPA Ita 90, IAC23, Coodetec 406, BRS Aroeira, MG 405, Fabrika, BRS Ipê, Fibermax 986, Coodetec 407, IAC-24, Makina, IAC 20-233, Shrow Grow 618, Coodetec 401, Delta Opal, CNPA Acala I, IAC-22, and BRS Itaúba.

Whitefly rearing - Adults were acquired from colonies in Campinas, São Paulo State, Brazil, previously identified as B. tabaci B-biotype by silvering induction in pumpkin leaves. The insects were multiplied (stock rearing) in a shade house, on cabbage (Brassica oleraceae var. capitata) and drunkard's dream plants (Euphorbia pulcherrima Willd). New plants were introduced every fifteen days to replace old plants already weakened by the high whitefly population present during rearing.

Attractiveness test - A split-plot design was used, with plots arranged in randomized blocks, in which the 20 genotypes represented treatments, with six replicates. Twenty-day-old cotton plants were submitted to artificial infestation with 100 non-sexed $B$. tabaci B-biotype adults per plant. Adult whitefly counts per genotype were determined 24,48 , and 72 hours after infestation. These counts were performed at sunset, on the underside of the first completely developed leaf from the apex, when the adults showed little mobility.

Non-Preference for oviposition tests - A randomized block design with 20 treatments and six replicates was used in the free-choice and no-choice tests. Twenty-day-old cotton plants were submitted to arti- ficial infestation with 100 non-sexed B. tabaci B-biotype adults per plant. In the no-choice test, a cylindrical iron cage, measuring $0.40 \mathrm{~m}$ in diameter by 0.60 $\mathrm{m}$ in height was used in each pot; the cage was wrapped with voile fabric to protect the plant before the release of whitefly adults. The first completely developed leaf from the apex of each plant was collected three days after infestation. Upon identification, the leaves were taken to the laboratory to count the number of eggs per $\mathrm{cm}^{2}$. A $1 \mathrm{~cm}^{2}$ template and a stereoscopic microscope were used to count the eggs. The trichome and gossypol gland densities per $\mathrm{cm}^{2}$ on the abaxial surface were also evaluated in the free-choice test.

The values obtained for each variable were submitted to analysis of variance and test F. When significant, the means were compared by Tukey test, at $5 \%$.

\section{RESULTS AND DISCUSSION}

Attractiveness test - No differences were observed among the cotton genotypes evaluated with regard to the mean number of $B$. tabaci B-biotype adults during each evaluation period $\left(F=0.99^{\text {ns }}\right)$; (Table 1). One day after infestation, the number of whiteflies in the genotypes varied from 4.5 to 55.8 adults per plant. In this period, the genotypes CNPA Acala I and IAC 20-233 had higher number of adults than 50, while Coodetec 407 attracted less than 5. The variation in number of whiteflies per plant among cotton genotypes (10 to 58.8 and 5.3 to 82.2 adults per plant), observed two and three days after infestation, respectively, indicates that factors of a morphological and/or chemical nature present in the plants accounted for greater or smaller whitefly attractiveness.

A higher number of adults was found in CNPA Acala I, while IAC 01-639 CPA 02-24, Coodetec 407, Shrow Grow 618, and Makina had less. Differences among cotton genotypes were observed for the mean number of $B$. tabaci B-biotype adults during the three evaluation periods $(F=3.03 * *)$. Genotype CNPA Acala I proved to be the most attractive, and genotypes Fabrika, CNPA Ita 90, Makina, Coodetec 407, and IAC 01-639 CPA 02-24 were the least attractive. When the means for the adult populations at 24,48 , and $72 \mathrm{~h}$ are compared in the horizontal direction (Table 1), they underwent non-significant variation, indicating that the plant/adult whitefly relationships during the evaluations did not interfere with the attractiveness test results.

The selection of more suitable plants for feeding and oviposition by B. tabaci (Van Lenteren \& Noldus, 1990) is conditioned by visual (Prokopy \& Owens, 1983), olfactive (Visser, 1988; Van Lenteren \& Noldus, 1990); taste (Stadler, 1986); shape and 
Table 1 - Mean ( \pm SE) number Bemisia tabaci B-biotype adults for 20 cotton genotypes, 24, 48, and 72 hours after infestation, in a free-choice test. Jaboticabal-SP, 2004.

\begin{tabular}{|c|c|c|c|c|}
\hline \multirow[t]{2}{*}{ Genotype } & \multicolumn{3}{|c|}{ Evaluation period (hours) } & \multirow[t]{2}{*}{ Mean } \\
\hline & 24 & 48 & 72 & \\
\hline CNPA Acala I & $55.8 \pm 15.92$ & $58.8 \pm 17.92$ & $82.2 \pm 24.47$ & $65.6 \mathrm{a}$ \\
\hline MG 405 & $49.8 \pm 16.17$ & $57.5 \pm 12.33$ & $38.8 \pm 16.40$ & $48.7 \mathrm{ab}$ \\
\hline Coodetec 401 & $36.3 \pm 3.04$ & $38.7 \pm 9.85$ & $43.5 \pm 12.80$ & $39.5 \mathrm{ab}$ \\
\hline IAC $20-233$ & $51.5 \pm 19.73$ & $35.7 \pm 9.28$ & $28.7 \pm 12.15$ & $38.6 \mathrm{ab}$ \\
\hline IAC-22 & $38.0 \pm 5.50$ & $31.0 \pm 5.39$ & $38.8 \pm 17.33$ & $35.9 \mathrm{ab}$ \\
\hline BRS Ipê & $21.5 \pm 4.75$ & $39.8 \pm 16.43$ & $39.8 \pm 14.68$ & $33.7 \mathrm{ab}$ \\
\hline BRS Aroeira & $24.0 \pm 6.89$ & $30.2 \pm 11.67$ & $30.7 \pm 7.10$ & $28.3 \mathrm{ab}$ \\
\hline PR 94-227-918 & $26.8 \pm 12.37$ & $27.7 \pm 13.41$ & $32.2 \pm 12.75$ & $28.9 \mathrm{ab}$ \\
\hline BRS Itaúba & $21.0 \pm 9.20$ & $22.2 \pm 9.84$ & $21.0 \pm 9.28$ & $21.4 \mathrm{ab}$ \\
\hline Delta Opal & $17.8 \pm 5.82$ & $29.2 \pm 9.84$ & $12.3 \pm 4.30$ & $19.8 \mathrm{ab}$ \\
\hline IAC- 23 & $9.5 \pm 2.23$ & $25.2 \pm 11.47$ & $23.8 \pm 6.80$ & $19.5 \mathrm{ab}$ \\
\hline Coodetec 406 & $11.7 \pm 5.52$ & $25.5 \pm 10.34$ & $13.5 \pm 5.12$ & $16.9 \mathrm{ab}$ \\
\hline IAC-24 & $19.2 \pm 5.59$ & $10.2 \pm 3.05$ & $15.2 \pm 6.78$ & $14.8 \mathrm{ab}$ \\
\hline Fibermax 966 & $20.2 \pm 8.36$ & $13.2 \pm 3.17$ & $10.7 \pm 4.54$ & $14.7 \mathrm{ab}$ \\
\hline Shrow Grow 618 & $15.7 \pm 5.43$ & $13.7 \pm 2.81$ & $9.5 \pm 2.95$ & $12.9 \mathrm{ab}$ \\
\hline Fabrika & $7.8 \pm 2.18$ & $10.7 \pm 2.97$ & $24.8 \pm 11.98$ & $14.4 \mathrm{~b}$ \\
\hline CNPA Ita 90 & $30.7 \pm 25.97$ & $12.8 \pm 9.67$ & $10.0 \pm 2.38$ & $17.8 \mathrm{~b}$ \\
\hline Makina & $13.2 \pm 5.47$ & $10.0 \pm 3.06$ & $11.0 \pm 3.71$ & $11.4 \mathrm{~b}$ \\
\hline Coodetec 407 & $4.5 \pm 1.06$ & $15.7 \pm 8.49$ & $10.7 \pm 3.74$ & $10.3 \mathrm{~b}$ \\
\hline IAC $01-639$ CPA $02-24$ & $7.7 \pm 1.80$ & $10.3 \pm 3.76$ & $5.3 \pm 1.20$ & $7.8 \mathrm{~b}$ \\
\hline Mean & $24.1 \mathrm{~A}$ & $25.9 \mathrm{~A}$ & $25.1 \mathrm{~A}$ & \\
\hline F (treatment) & & & & $3.03^{* *}$ \\
\hline F (hours) & & & & $0.44^{\mathrm{NS}}$ \\
\hline F (treatment $\times$ hours) & & & & $0.99^{\mathrm{NS}}$ \\
\hline CV (treatment) $(\%)$ & & & & 72.26 \\
\hline $\mathrm{CV}$ (hours) $(\%)$ & & & & 33.58 \\
\hline
\end{tabular}

$\mathrm{SE}=$ Standard error of the mean; Original and analysis data were transformed to $(\mathrm{x}+0.50)^{1 / 2}$ for ANOVA; Means followed by the same letter do not differ by Tukey test, $(P=0.05)$. **denotes the $F$ value is significantly at $P=0.01$.

structural (Van Lenteren \& Noldus, 1990); and leafcolor stimuli (Husain \& Trehan, 1940; Mau \& Kessing, 2002) in addition to their quality, chemical makeup and age (Walker \& Perring, 1994). In this respect, Chu et al. (1995) believe that preference for oviposition sites by $B$. tabaci B-biotype in cotton plants is influenced by gravity, light, and their interactions with the leaf structure, as well as by environmental conditions and natural enemies.

Non-Preference for oviposition tests - In the free-choice test (Table 2), higher quantities of eggs per $\mathrm{cm}^{2}\left(F=6.96^{* *}\right)$ were observed for genotypes IAC-23, Coodetec 407, Shrow Grow 618, and CNPA Acala I, and lower quantities were observed for IAC-24, BRS Ipê, Fabrika, Coodetec 406, and BRS Aroeira. Trichome density of genotype Coodetec 401 was higher than those observed for the other evaluated genotypes. CNPA Acala I, IAC 20-233, and BRS Aroeira were more pubescent, while IAC-23, Coodetec 407, Makina, CNPA Ita 90, BRS Itaúba, Delta Opal, Fibermax 966, IAC-24, BRS Ipê, Fabrika, and Coodetec 406 were glabrous. The results for Makina, CNPA Ita 90, Fabrika, Delta Opal, and BRS Itaúba, without trichomes, and for Coodetec 401, pubescent, were coincident with those found by Campos (2003) in an investigation developed in Ilha Solteira-SP, Brazil, while genotypes IAC-23, BRS Aroeira, BRS Ipê, and IAC-22 presented differences with regard to number of trichomes per $\mathrm{cm}^{2}$. This variation in number of trichomes per $\mathrm{cm}^{2}$ from place to place may be influenced by the environmental conditions, such as moisture, light, temperature, and soil characteristics (Lara, 1991). 
Table 2 - Mean ( \pm SE) number of Bemisia tabaci B-biotype eggs, mean number of trichomes, and mean number of gossypol glands for 20 cotton (G. hirsutum) genotypes, in a free-choice test. Jaboticabal-SP, 2004.

\begin{tabular}{|c|c|c|c|}
\hline Genotype & Eggs $\mathrm{cm}^{-2}$ & Trichomes $\mathrm{cm}^{-2}$ & Gossypol Glands $\mathrm{cm}^{-2}$ \\
\hline IAC-23 & $57.1 \pm 8.19 \mathrm{a}$ & $0.0 \pm 0.00 \mathrm{f}$ & $128.0 \pm 5.13 \mathrm{ab}$ \\
\hline Coodetec 407 & $49.8 \pm 6.90 \mathrm{ab}$ & $0.0 \pm 0.00 \mathrm{f}$ & $104.5 \pm 6.45$ bcdef \\
\hline Shrow Grow 618 & $49.2 \pm 5.63 \mathrm{ab}$ & $15.0 \pm 3.31 \mathrm{de}$ & $136.8 \pm 3.10 \mathrm{a}$ \\
\hline CNPA Acala I & $49.3 \pm 9.81 \mathrm{abc}$ & $44.2 \pm 9.21 \mathrm{~b}$ & $99.8 \pm 4.90$ bcdef \\
\hline Makina & $38.8 \pm 6.52 \mathrm{abcd}$ & $0.0 \pm 0.00 \mathrm{f}$ & $89.2 \pm 4.51 \mathrm{def}$ \\
\hline IAC $20-233$ & $37.3 \pm 5.82 \mathrm{abcd}$ & $40.2 \pm 6.31 \mathrm{bc}$ & $111.8 \pm 3.53 \mathrm{abcd}$ \\
\hline PR 94-227-918 & $33.4 \pm 3.36 \mathrm{abcd}$ & $7.3 \pm 2.40 \mathrm{e}$ & $92.8 \pm 5.85 \mathrm{def}$ \\
\hline IAC 01-639 CPA 02-24 & $30.8 \pm 3.54 \mathrm{abcd}$ & $0.2 \pm 0.17 \mathrm{f}$ & $78.0 \pm 5.41 \mathrm{f}$ \\
\hline CNPA Ita 90 & $27.5 \pm 4.81$ abcde & $0.0 \pm 0.00 \mathrm{f}$ & $100.8 \pm 6.27$ bcdef \\
\hline BRS Itaúba & $26.5 \pm 7.09$ bcde & $0.0 \pm 0.00 \mathrm{f}$ & $106.5 \pm 6.06$ abcde \\
\hline IAC-22 & $24.6 \pm 9.26$ bcde & $16.2 \pm 2.99 \mathrm{de}$ & $80.0 \pm 5.89$ ef \\
\hline Delta Opal & $24.0 \pm 2.76 \mathrm{bcde}$ & $0.0 \pm 0.00 \mathrm{f}$ & $101.0 \pm 6.01 \mathrm{bcdef}$ \\
\hline Fibermax 966 & $21.9 \pm 3.45$ bcde & $0.5 \pm 0.34 \mathrm{f}$ & $94.3 \pm 5.70 \mathrm{def}$ \\
\hline MG 405 & $21.5 \pm 2.15$ bcde & $23.8 \pm 3.29 \mathrm{~cd}$ & $95.0 \pm 5.59 \mathrm{cdef}$ \\
\hline Coodetec 401 & $19.8 \pm 4.49 \mathrm{cde}$ & $151.3 \pm 8.04 \mathrm{a}$ & $127.7 \pm 6.10 \mathrm{abcd}$ \\
\hline IAC-24 & $16.5 \pm 3.88 \mathrm{de}$ & $0.0 \pm 0.00 \mathrm{f}$ & $104.5 \pm 6.90 \mathrm{bcdef}$ \\
\hline BRS Ipê & $15.3 \pm 1.59 \mathrm{de}$ & $0.0 \pm 0.00 \mathrm{f}$ & $124.8 \pm 7.33 \mathrm{abc}$ \\
\hline Fabrika & $14.3 \pm 3.56 \mathrm{de}$ & $0.0 \pm 0.00 \mathrm{f}$ & $89.2 \pm 1.72 \mathrm{def}$ \\
\hline Coodetec 406 & $13.9 \pm 2.21 \mathrm{de}$ & $0.0 \pm 0.00 \mathrm{f}$ & $111.0 \pm 3.96 \mathrm{abcd}$ \\
\hline BRS Aroeira & $8.8 \pm 2.81 \mathrm{e}$ & $36.5 \pm 5.84 \mathrm{bc}$ & $111.3 \pm 8.41 \mathrm{abcd}$ \\
\hline F (treatment) & $6.96 * *$ & $92.86 * *$ & $7.15 * *$ \\
\hline $\mathrm{CV}(\%)$ & 22.88 & 27.29 & 6.70 \\
\hline
\end{tabular}

$\mathrm{SE}=$ Standard error of the mean; Original and statistical analysis data were transformed to $(\mathrm{x}+0.50)^{1 / 2}$ for ANOVA; Means followed by the same letter do not differ by Tukey test $(P=0.05)$. **denotes the $F$ value is significantly at $P=0.01$.

The glabrous genotypes IAC-24, BRS Ipê, Fabrika, and Coodetec 406 showed a small number of eggs, while the pubescent genotype CNPA Acala I a high number. These results were also found by Mound (1962), Butler Jr. \& Henneberry (1984), Berlinger (1986), Butter \& Vir (1989), Wilson et al. (1993), Toscano et al. (2003), and Campos (2003), who observed a smaller number of eggs in less-pubescent or glabrous genotypes, and a higher number of eggs in pubescent genotypes. However, higher oviposition was verified for genotypes IAC-23 and Coodetec 407, with glabrous leaves; BRS Aroeira, a pubescent-leaved genotype, received little oviposition; and relatively little oviposition was observed for Coodetec 401, a highly pubescent genotype, which suggests that other traits of these genotypes may be influencing the oviposition process.

With reference to gossypol (Table 2), the number of glands ranged from 78.0 per $\mathrm{cm}^{2}$ for genotype IAC 01-639 CPA 02-24 to 136.8 glands per $\mathrm{cm}^{2}$ for genotype Shrow Grow. In general, the results do not allow a correlation to be established between number of eggs per $\mathrm{cm}^{2}$ and number of trichomes per $\mathrm{cm}^{2}(\mathrm{r}=0.09)$, number of eggs per $\mathrm{cm}^{2}$ and gossypol glands per $\mathrm{cm}^{2}$ $(\mathrm{r}=0.19)$, and number of trichomes per $\mathrm{cm}^{2}$ and gossypol glands per $\mathrm{cm}^{2}(\mathrm{r}=0.11)$ in the free-choice test. Butter et al. (1990) found a negative correlation $(r=-0.45)$ between gossypol content and the egg density of B. tabaci A-biotype, while Butter \& Vir (1989) reported a positive correlation $(r=0.53)$ between number of $B$. tabaci A-biotype adults and number of gossypol glands on the internodes of the main stem of cotton plants.

In the no-choice oviposition preference test (Table 3), the mean number of eggs $/ \mathrm{cm}^{2}$ for genotypes Shrow Grow 618, Coodetec 401, BRS Aroeira, Coodetec 407, Fabrika, and Coodetec 406 were lower $\left(F=12.77^{* *}\right)$ than those observed for genotypes CNPAAcala I and IAC-23. Considering the free-choice and no-choice tests, BRS Aroeira, Coodetec 406, Fabrika, and Coodetec 401 were the least oviposited, indicating the occurrence of non-preference for oviposition in these genotypes, consisting in sources of resistance to this whitefly. In Ilha Solteira-SP, Campos (2003) 
Table 3 - Mean ( \pm SE) number of Bemisia tabaci B-biotype eggs for 20 cotton ( $G$. hirsutum) genotypes in a no-choice test. Jaboticabal-SP, 2004.

\begin{tabular}{|c|c|}
\hline Genotypes & Eggs $\mathrm{cm}^{-2}$ \\
\hline CNPA Acala I & $20.5 \pm 1.91 \mathrm{a}$ \\
\hline IAC-23 & $18.5 \pm 1.71 \mathrm{ab}$ \\
\hline BRS Itaúba & $16.7 \pm 2.00 \mathrm{abc}$ \\
\hline IAC-24 & $16.5 \pm 2.28 \mathrm{abc}$ \\
\hline IAC 01-639 CPA 02-24 & $16.3 \pm 3.07 \mathrm{abc}$ \\
\hline BRS Ipê & $16.2 \pm 2.18 \mathrm{abc}$ \\
\hline IAC $20-233$ & $15.8 \pm 1.89 \mathrm{abc}$ \\
\hline Delta Opal & $14.8 \pm 2.32 \mathrm{abcd}$ \\
\hline Makina & $13.9 \pm 1.01 \mathrm{abcde}$ \\
\hline PR 94-227-918 & $13.6 \pm 2.06 \mathrm{abcde}$ \\
\hline IAC-22 & $12.5 \pm 1.77$ abcdef \\
\hline MG 405 & $10.6 \pm 1.80 \mathrm{bcdefg}$ \\
\hline CNPA Ita 90 & $9.7 \pm 2.53$ cdefgh \\
\hline Fibermax 966 & $9.1 \pm 1.34$ cdefgh \\
\hline Coodetec 406 & $6.9 \pm 0.82$ defghi \\
\hline Fabrika & $6.3 \pm 1.19$ efghi \\
\hline Coodetec 407 & $5.1 \pm 1.00 \mathrm{fghi}$ \\
\hline BRS Aroeira & $4.1 \pm 0.80 \mathrm{ghi}$ \\
\hline Coodetec 401 & $3.1 \pm 0.93 \mathrm{hi}$ \\
\hline Shrow Grow 618 & $2.2 \pm 0.31 \mathrm{I}$ \\
\hline F (treatment) & $12.77 * *$ \\
\hline $\mathrm{CV}(\%)$ & 18.09 \\
\hline
\end{tabular}

$\mathrm{SE}=$ Standard error of the mean; Original and statistical analysis data were transformed to $(\mathrm{x}+0.50)^{1 / 2}$ for ANOVA; Means followed by the same letter do not differ by Tukey test $(P=$ $0.05)$. **denotes the $F$ value is significantly at $P=0.01$.

found lower B. tabaci B-biotype oviposition preference for genotypes BRS Aroeira and Fabrika.

The low attractiveness of plants from genotypes Fabrika, CNPA Ita 90, Makina, Coodetec 407, and IAC 01-639 CPA 02-24 to B. tabaci B-biotype may represent a resistance component of these genetic materials to the B. tabaci B-biotype whitefly. Genotypes BRS Aroeira, Coodetec 406, Fabrika, and Coodetec 401 presented the non-preference-for-oviposition type of resistance to whitefly in the free-choice and no-choice tests. The numbers of trichomes and gossypol glands per $\mathrm{cm}^{2}$ were not suitable to evaluate non-preference for oviposition of whitefly adults on cotton genotypes.

\section{REFERENCES}

BENTZ, J.; REEVES III, J.; BARBOSA, P.; FRANCIS, B. Within-plant variation in nitrogen and sugar content of poinsettia and its effects on the oviposition pattern, survival, and development of Bemisia argentifolii (Homoptera: Aleyrodidae). Environmental Entomology, v.24, p.271-277, 1995.
BERLINGER, M.J. Host plant resistance to Bemisia tabaci. Agriculture Ecosystems and Environment, v.17, p.69-82, 1986.

BUTLER JR., G.D.; HENNEBERRY, T.J. Bemisia tabaci: effect of cotton leaf pubescence on abundance. Southwestern Entomologist, v.9, p.91-94, 1984.

BUTTER, N.S.; VIR, B.K. Morphological basis of resistance in cotton to the whitefly Bemisia tabaci. Phytoparasitica, v.17, p.251-261, 1989.

BUTTER, N.S.; VIR, B.K.; KAUR, G.; SINGH, T.H.; RAHEJA, R.K. Biochemical basis on resistance to whitefly Bemisia tabaci Genn. (Aleyrodidae: Homoptera) in cotton. Tropical Agriculture, v.69, p.119-122, 1990.

CAMPOS, O.R. Resistência de genótipos de algodoeiro a mosca branca Bemisia tabaci (Gennadius 1889) biótipo B (Hemiptera: Aleyrodidae). Botucatu: UNESP/FCA, 2003. 69p. (Tese-Doutorado).

CHU, C.C.; HENNEBERRY, T.J.; COHEN, A.C. Bemisia argentifolii (Homoptera, Aleyrodidae): host preference and factors affecting oviposition and feeding site preference. Environmental Entomology, v.24, p.354-360, 1995.

HUSAIN, M.; TREHAN, K.N. Final report on the scheme of investigations on the whitefly on cotton in the Punjab. Indian Journal of Agricultural Science, v.10, p.101-109, 1940.

LARA, F.M. Princípios de resistência de plantas a insetos. São Paulo: Ícone, 1991. 336p.

MAU, R.F.L.; KESSING, J.L.M.Bemisia tabaci (Gennadius). Available at: 〈http://www.extento.hawaii.edu/kbase/crop/Type/b_tabaci.htm> Access in: 03 set. 2002.

McAUSLANE, H.J. Influence of leaf pubescence on ovipositional preference of Bemisia argentifolii (Homoptera: Aleyrodidae) on soybean. Environmental Entomology, v.25, p.834-841, 1996.

MOUND, L.A. Studies on the olfaction and colour sensitivity of Bemisia tabaci (Gennadius) (Homoptera: Aleyrodidae). Entomologia Experimentalis et Applicata, v.5, p.99-104, 1962.

NORMAN JR., J.W.; RILEY, D.G.; STANSLY, P.A.; ELLSWORTH, P.C.; TOSCANO, N.C. Management of Silverleaf Whitefly: a comprehensive manual on the biology, economic impact and control tactics. College Station: University of Texas, 1996. 22p.

PROKOPY, R.J.; OWENS, E.D. Visual detection of plants by herbivorous insects. Annual Review of Entomology, v.28, p.337364, 1983.

SIPPELL, D.W.; BINDRA, O.S.; KHALIFA, H. Resistance to whitefly (Bemisia tabaci) in cotton (Gossypium hirsutum) in the Sudan. Crop Protection, v.6, p.171-178, 1987.

STADLER, E. Oviposition and feeding stimuli in leaf surface waxes. In: JUPINER, B.E.; SOUTHWOOD, T.R.E. (Ed.). Insects and the plant surface. London: Chapman \& Hall, 1986. p.105-121.

TOSCANO, L.C.; SANTOS, T.M.; BOIÇA JR., A.L. Preferência de Bemisia tabaci biótipo B para oviposição em cultivares de algodoeiro. Pesquisa Agropecuária Brasileira, v.38, p.155-160, 2003.

VAN LENTEREN, J.A.; NOLDUS, L.P.J.J. Whitefly-plant relationships: behavioral and ecological aspects. In: GERLING, D. (Ed.). Whiteflies: their bionomics, pest status and management. Andover: Intercept, 1990. p.47-89.

VISSER, J.H. Host-plant finding by insects: orientation, sensory input and search patters. Journal of Insect Physiology, v.34, p.259-268, 1988.

WALKER, G.P.; PERRING, T.M. Feeding and oviposition behavior of whiteflies (Homoptera: Aleyrodidae) interpreted from AC electronic feeding monitor waveforms. Annals of the Entomological Society of America, v.18, p.363-374, 1994.

WILSON, F.D.; FLINT, H.M.; STAPP, B.R.; PARKS, N.J. Evaluation of cultivars, germplasm lines, and species of Gossypium for resistance to biotype "B" of sweet potato whitefly (Homoptera: Aleyrodidae). Journal of Economic Entomology, v.86, p.1857-1862, 1993. 